\title{
Critical Environmental Challenges in the Niger Delta: Exploring Strategic Solutions
}

\author{
Sofiri Joab-Peterside \\ Department of Sociology, University of Port Harcourt, Rivers State, Nigeria
}

\begin{abstract}
The Oil industry is the most important sector in the Niger Delta economy while other industries play a minor role only. Consequently, it is not possible to comprehend the environmental crises plaguing the region without paying special attention to the multinational oil companies' phenomenon, because it particularly salient to the long and terrible record of environmental degradation which has gone on unchecked for over fifty years. The emergence of makeshift refineries as mechanisms of illegal access to oil resources by residents have accentuated the environmental and health problems for the people because the environment is being destroyed daily through Oil spillage and disposal of waste from crude refining across the creeks and waterways. The degradation of the environment from pollution of running waters to rivers and the destruction of farmlands is monumental and catastrophic. Solid waste management, as it appears, is the most pressing environmental challenge faced by urban and rural areas in the region and with the population explosion of the major cities, the problem of solid waste management is assuming alarming proportions. Government have initiated and implemented various policies to address the problems yet, the degradation subsists largely because the policies are not sustainable.
\end{abstract}

Keywords: Environmental Challenges, Niger Delta, Oil Industry, Pollution, Sustainable Policies

DOI: $10.7176 / \mathrm{DCS} / 9-7-03$

Publication date:July $31^{\text {st }} 2019$

\section{Introduction}

Niger Delta has historically played and continues to play a critical and strategic role in the development of Nigeria and its economic relations with the wider world. This is due as much to its geopolitical location, its geophysical structure and characteristics, and its rich human, water, forest/land and mineral resource endowment. If the region has played and continues to play this historical role in defining and contributing to economic life of the Nigerian state, it has itself been affected and transformed, both for ill and good, by the dynamics and contradictions of political and economic development in the country and by the wider world political economy, within which the oil and gas industry has assumed prime importance.

It is of importance to emphasize this point about the historical immersion of Niger Delta as one of the influential players in the Nigeria's petro-economy, if we are to understand the intricate complex relationship between oil, the oil and gas industry and Niger Delta environmental challenges. This is a central dimension of the argument I seek to advance in this paper. What I offer here are more or less elements of this argument to provide a useful approach to looking at the relation between the oil and gas industry and the Region's environmental challenges. Against this backdrop, the aim of this paper is three-fold. First, is to provide an account of the extent and types of damage done to the environment by oil exploration activities in Niger Delta with Rivers State as the focal point. Second, to draw attention to government's efforts at solving the problem associated thereto and why these efforts will not attain the desired objectives. Third, to investigate what can be done to ameliorate the hazards in context of seeming lack of political commitment in this regard even in the midst of subsisting policies. The final section summarizes and concludes the argument.

In assessing the consequences of the Region's environmental challenges we must not gloss over the fact of the relative newness of environmental concerns. The point of fact is that for government and industry, the driving force for early period of production into the 1990s was profit rather environmental concerns; the primary focus was on oil revenue sharing between the three tiers of government. No conscious effort was made to value the enormous costs of oil and gas activities to the environment and communities. Policies and enforcement were very limited (Chokor, 2006). It is even doubtful if there is an instrument to deduct the environmental costs of exploration and production activities before arriving at the net profit as is done in other climes. Yet, the environment is a complex weave of physical, chemical and biotic that interact with each other and impact on all living things and their surroundings. This implies that the environment is the life support system for human existence and survival, providing also, the physical milieu and raw materials required for socio-economic progress. However, the quest for human survival has resulted in rapid expansion and intensification of economic activities which are largely resource intensive (The Guardian, 2004). The human assault on the environment in the course of promoting and advancing development has resulted in environmental threats such as global warming, loss of biological diversity and pollution of the lower atmosphere including the ocean. Consequently, there is a growing concern over the environmental consequences of economic development, particularly as it relates to sustainable development in the oil producing communities. This has become more crucial in the face of persistent and worsening poverty, despite 
the huge revenue generate by crude oil exploration hence, justifying the focus on the Niger Delta. The next section presents the nature of the environmental challenges in the region.

\section{Nature of the Environmental Challenges in the Niger Delta region}

The Niger Delta is the richest part of Nigeria in terms of its natural resource endowment. The area has large oil and gas deposits, as well as extensive forests, good agricultural land and abundant fish resources all of which is now history. Unfortunately, despite the tremendous natural and human resource base, the region's potential for sustainable development remains unfulfilled partly because it is threatened by environmental degradation and deteriorating socio-economic conditions not being holistically addressed by present policies and state act. Over fifty years of oil exploration and exploitation in the region is yet to bring significant development to the Region. In fact, the area is characterized by poor health care system, stagnant agricultural productivity, very limited opportunities for survival in urban areas, rapid population growth, and tenuous property rights. Despite its vast oil reserves, the region remains poor (Moffat and Lindin, 1995).

Nevertheless, oil production has transformed the local economy, and in some oil producing communities have benefited immensely from oil production. For example, those with full time employment in the oil industry are paid higher for skilled work. However, they a well-paid minority surrounded by an army of underemployed; most in any event, do not come from the oil producing communities. Contractors to the oil companies are often traditional rulers or those with close links to the oil producing State/Federal governments. There are instances where development spending by oil companies has resulted in the building of schools, health centres and other infrastructure in areas so remote. Unfortunately, many of the "Corporate Development" projects are inappropriate for the needs of the communities where they are cited, with others abandoned or shoddily executed (Human Rights Watch, 1999).

The Delta is a vast floodplain built up by the accumulation of sedimentary deposits washed down the Niger and Benue rivers. The Niger River has the ninth largest drainage area of the world's rivers and the third largest in Africa, $2.23 \mathrm{mil} / \mathrm{km} 3$ (Rangeley, 1994). It is composed of four ecological zones namely, coastal barrier islands, mangroves, freshwater swamp forests, and low-land forests. Mangrove forest of Nigeria is the third largest in the world and the largest in Africa over sixty percent of which is found in the Niger Delta $(6000 \mathrm{~km} 2)$. However, the freshwater swamp forests of the delta are considerably larger and the most extensive in west and central Africa. Unfortunately, with the high rates of deforestation in the rest of Nigeria, regrettably uncontrolled logging and agricultural encroachment are also persistently degrading this forest zone. Consequently, most of the lowland rainforest is at present derived savannah with small areas of intact forest remaining. The high rainfall and river discharge during the long rainy season combined with the low, flat terrain and poorly drained soils, cause widespread flooding and erosion (Moffat and Lindin, 1995). In fact, over eighty percent of the delta is seasonally flooded especially, Bayelsa, Delta, and Rivers States. When the floodwater recedes, the channels that spread across the Niger Delta leave swamps and pools that drain poorly. Also, River bank erosion results in loss of land annually. With the present trend, about $40 \%$ percent of the current inhabited land in the delta will be lost in the next thirty years. Since riverbank levels are the most populated areas and are intensively cultivated, riverbank erosion results in the loss of some of the most valuable land in the Niger Delta (Ibe and Awosika, 1989; Abam, 1995). Biophysically, land in the Niger Delta is expressed in a dynamic and complex ecology, topography and vegetation, much of being fragile wetland. Economically, land is central to change from peasant economy; through a cash crop economy to the present petro-economy. Oil related operations are the most obvious industrial activity in the Niger Delta. Unfortunately, oil production has damaging effects on the environment of oil producing communities because economically, the lives and livelihoods of the inhabitants are essentially based on farming, fishing and exploitation of the rich forest resources. The mangrove forest has the high biodiversity typical of extensive swamp and forest areas, with many unique species of plants and animals. Despite decades of oil production, until the United Nations Environmental Programme (UNEP) Environmental Assessment of Ogoni land report, there is surprisingly little good quality independent scientific data on the overall or long-term effects of hydrocarbon pollution, yet oil -led development has seriously damaged the environment and the livelihood of many of those living in the oil producing communities (Human Rights Watch, 1999; UNEP, 2011).

There are three basic ways in which oil operations impact on land and the environment. First is through exploration which is the first stage in oil exploration during which potential reserves are identified through seismic surveys, usually carried out with the use of explosives on land, and with air guns on water. If on land, this process requires access to often large tracts of land. Second, is drilling which commences where seismic surveys were successful. A drilling location occupying between 5,000 and 20,000 square metres is required for oil. This is not the only impact on land because securing access to location on mangrove swamps usually dredging shallow and narrow creeks so that drilling rigs and barges could be moved in. this has consequences on surrounding as the land may become more flooded than before as more water is introduced into the area than before (Dulue \& Nwankwo, 2001). Drilling also produces waste, which could be harmful to the environment (UNEP, 2011), yet, the oil companies operating in Nigeria maintain that their activities are conducted according to the highest environmental 
standards. The point of fact is that Nigerian environmental laws, in most respects comparable to their international equivalents, are poorly enforced.

Successful completion of drilling is usually accompanied by field development and production. It is at this stage that a network of pipelines is used to link up the oil wells to the flow stations; here gas is separated (and flared off in Nigeria) with the remaining mixture of oil and water pumped to the export terminals where the two are separated and the oil is exported. Impacts on the environment arising from field development and production includes the flaring of gas, the disposal of wastes, chemicals and sludge and spills. Apart from the health risks to which inhabitants of the communities are exposed by pollution, they also suffer loss of economic activities. Fishing activity suffers as fish die from pollution or migrate elsewhere. Farmers are dislodged from the soil they have been using for many years, worse still, all these losses are not adequately by either the compensation paid or the system of paying compensation (Dulue \& Nwankwo, 2001). It is therefore not a surprise that the negative impact of petroleum production on land-based livelihoods has been the major contentious issue between the local communities, oil companies and the Nigerian state.

Environmental degradation resulting from oil spill has become a major source of environmental pollution in Niger Delta causing serious damage to marine life and vas destruction to the fragile mangrove environment. For example, poorly designed causeways and canals used by the oil industry affects the hydrology of the seasonally flooded freshwater swamp and brackish water of the mangrove forest. The environmental consequences include destruction of crops and fishing grounds, and the damaging of potable water supply. Worse still, compensations for such damages when paid, are grossly inadequate, and in the absence of environmental friendly courts, absence of an effective independent arbiter to determine the value of property damaged, coupled with the high cost of accessing justice, the oil companies operate at their own whims and caprices.

At the heart of the environmental challenges are oil spills, gas flaring and crude oil theft. According to industry sources, three sources of spills have been identified namely, equipment failure, human error and sabotage. Equipment failure may derive from overflow at loading terminals, or valve failure which results in pressure problems; rupture and/or corrosion of pipes and underground equipment which results in bursts, leakages and blowouts; worn-out equipment due to age of equipment. Human error accidents can be traced to lack of concentration and distractions by persons performing legitimate tasks. Specifically, this can result from physical stress due to smoking, drugs, (alcohol), lack of sleep and fatigue. Industry sources defined sabotage spills as deliberate and malicious damage of oil pipelines and equipment by persons or group of persons. This implies that human error can be attributed to negligence or failure (Nwankwo, 1984; Oduchi, 1992, Remani-Abah Consultants, 1997; Aprioku, 1999).

Sabotage, on the other hand, can be explained as deliberate and malicious damage of oil pipelines and equipment by persons or group of persons. This kind of damage is distinguished from that of human error and equipment failure spills because they are perpetrated to obstruct the smooth evacuation of crude oil from wells to reservoirs. The major drivers of sabotage according to Akujuru (1992), are cutting of pipelines on community land to obtain compensation, compensation for damage was grossly inadequate, not paid or failed to reach affected communities; that individuals disrupted production to force companies to provide amenities to their communities. The oil companies often claim that many spills are caused by sabotage, and in accordance with the Nigerian law, the companies pay no compensation in such cases. Intriguingly, the determination that sabotage has occurred is largely left in the hands of the oil companies, increasing the chances of injustice and frustrations of inhabitants of oil bearing communities.

The oil industry apart from recording success in terms of revenue generation, has equally recorded some untoward success of environmental degradation in the Niger Delta. For example, from 1976 to 1996 a total of 4 , 647 oil spill incidents were recorded in the Niger Delta region. This figure represented a total quantity of 2 , $369,470.04$ barrels of crude oil spilled into the coastal environment. Out of this figure, only 549,060.38 barrels of crude were recovered, while 1, 820,410.50 barrels of crude oil were lost. This indicated that only 23.17 percent of the spilled oil was recovered, while 76.83 percent were lost within this period (Ugwoke-Omene, 2004). It is worrisome that not much has changed in terms of harm to the environment.

In most cases, oil spills result from corrosion of oil pipes, poor maintenance of infrastructure, leaks, human errors as well as vandalism or sabotage and oil theft. In theory, companies like Shell Petroleum Development Company (SPDC) operates a network of "modern pipelines and facilities hence, the company claims that oil spills are dealt with promptly by specialised teams with appropriate equipment. The realty in the Niger Delta is that SPDC has made some progress in pipeline maintenance and replacement, much oil still flows through pipe up to fifty years old. Oil spills in the Delta have been estimated as equivalent in volume to the Exxon Valdese disaster every (Brown, 2006). The situation is worse in recent years. It is a common practice to delay inspecting oil spills for over twenty-four hours, allowing much of the pollution to disperse thereby reducing the size of the spill reported. In fact, the oil companies operating in the region have become embroiled in a policy "breakdown" that is exploited by corrupt actors both inside and outside the companies (SDN, 2010). However, this is not an excuse for the companies' failure to uphold their environmental responsibilities. 
Oil spill have created opportunities for primitive capitalist accumulation by unscrupulous "inside and outside" actors. Oil spill incidents often times involve a company staff member, a contractor and proxies in affected communities who provide access to the spill, private security and personal security cover for delays that result in clean-ups being hugely expensive, often times, poorly conducted or often not undertaken at all even after collection of huge sums of money for the clean-up. For reasons of breakdown of trust, communities often refuse entry to oil companies' personnel and subcontractors sent assess oil spills. The obvious consequence of these further delays includes worsening pollution and bigger eventual contracts for the subcontractors and their sponsors. Community members with vested interest often times, take advantage of the situation by claiming that spills which resulted from bunkering (oil theft) and failed surveillance are the result of a pipeline fault (SDN, 2010).

There are instances where individuals identified as responsible for damaging pipelines have become directly involved with clean-ups or surveillance contracts. This often stokes community tension and conflict over compensation paid to community people whose lands have been affected by oil spills. Such tensions were one of the main factors implicated in the massacre in Odioma, a community in Bayelsa State in February, 2005 (Amnesty International, 2005; CEHRD, 2008). Worse still, the scale of pollution and environmental damage has never been properly assessed, while the regulatory systems and institutions are deeply flawed because laws and regulations that require companies to comply with internationally recognized standards of "good oil field practice" and laws and regulations designed to protect the environment, are poorly if at all, enforced.

The general trend is that government agencies responsible for enforcement are either ineffective or are not willing to hold companies accountable. The result is that the region has become a complex operating environment characterized by conflict. The major impacts of oil spills have been identified to include decrease of fisheries resources and damage to wildlife, sea and marine animals. Others include: human health hazards through eating of contaminated sea foods; decreases of aesthetic value due to slightly slicks on water bodies and oiled beaches; modification of marine ecosystems through elimination of species, decrease in ecological diversity, biomass and productivity, and habit modification leading to delay in re-colonization and succession (Aina, 1996; Chokor, 2006).

Apart from oil spills, waste dumping, and gas flaring are notorious and endemic in the region. The impact of disposal of waste from oil facilities is unknown. For example, due to lack of adequate facilities for treatment of oily or chemical waste, effluents from the refineries at Port Harcourt and Warri were usually discharged after treatment into the adjourning creeks and rivers. Nearby communities have complained at the effects of these affluent on fish stocks (Niger Delta Environmental Survey, 2011). When oil production began in the early 1950s and $60 \mathrm{~s}$, the cheapest way to separate the identified product, crude oil, from the associated natural gas was to burn the gas. With some 120 trillion cubic feet (about 20 billion barrels' oil equivalent, boe) of gas, Nigeria has the $10^{\text {th }}$ largest reserves in the world and second only to Algeria on the African continent. In energy terms, the reserve of natural gas in Nigeria is at least of the same order as the reserves of crude oil. Most of the gas produced is currently being flared; hence it has become a great concern to Nigeria. On the average, about 1000 standard cubic feet (scf) of gas in produced in the country with every barrel of oil. This is so because in many oil fields, large volumes of gas are produced with crude oil when it is brought to the surface. From 1971 to 1997 a total amount of $652,856,802.5 \mathrm{~m} 3$ of gas was in the Nigerian oil industry. While a total amount of 545,792, 922.4m 3 of gas were flared, representing $83.60 \%$ of the total amount produced, only $107,063,880.1 \mathrm{~m} 3$ of gas were utilized representing only 16.40 per cent (Ugwoke-Omene, 2004). Unfortunately, gas flaring not only wastes a potentially viable source of energy (natural gas), it also adds significant carbon emissions to the atmosphere. Statistics from the Department of Petroleum Resources (DPR) shows that Chevron has the largest volumes of gas flared within Nigeria with 82 percent, followed by ADDAX with 80 percent; Mobil, 39 per cent; Nigeria Agip Oil Company (NAOC), 25 per cent; SPDC, 19 per cent; and Elf, 16 per cent.

Every year, millions of dollars are literally going up in smoke in the Niger Delta as companies' burn off unwanted natural gas released during oil production. The Government at a time fixed December 2012 as the new deadline to end all forms of gas flaring in Nigeria. This was not to be feasible as the country is still rated the second worst gas flaring nation in the world after Russia. An estimated \$2.5 billion was reportedly lost yearly due to lack of infrastructure to harness gas. Worried about the health and environmental consequences of gas flares in the country, the Federal Government, a few years ago, directed oil producing companies to shut in oil fields where gas being produced and flared was considerably more than the crude oil produced. Yet the oil companies repeatedly flout legislative deadlines to gas flares. This is particularly true in the Niger Delta where much of the oil has a high proportion of this associated gas. With oil production of some 2.2 million barrels per day, about 2.2 billion scf of associate gas is produced every day (Omiyi, 2001). Out of the total associated gas produced about 17 per cent is re-injected, 33 percent is used commercially and the remaining 50 per cent is usually burned off- a process called flaring.

The World Bank reported that gas flare released more greenhouse gases than all other emissions sources in sub-Saharan Africa combined. Human health is a major casualty. The flares contain a cocktail of toxins that affect the health and livelihood of local communities, exposing Niger Delta residents to an increased risk of premature deaths, child respiratory illness, asthma and cancer (Friends of the Earth International, 2005). The point being 
made is that Gas flares have potentially harmful effects on the health and livelihood of communities in their vicinity because they release a variety of poisonous chemicals including nitrogen dioxides, sulphur dioxide, volatile organic compounds such as benzene, toluene, xylene and hydrogen sulphide, as well as carcinogens like benzapyrene and dioxin. Humans exposed to these substances are likely to suffer from a variety of respiratory problems. These chemicals can aggravate asthma and can also cause breathing difficulties and pain, as well as chronic bronchitis. Furthermore, benzene known to be emitted from gas flares in undocumented quantities, has been recognized as a cause of leukemia and other blood related diseases (Obayanju, 2011).

Specifically, the flare of gas has the following health implications:

- $\quad$ During the flare of gas hydrocarbons, benzene and methane, Nitrous result in thermal radiation budget alteration "climate change". Climate change leads to increased temperature which affects the human skins. The sea level rise, precipitation, directs solar radiation and its resultant depletion of the ozone layer, frequency of severe weather and loss of fresh water

- Naphthalene is an element which destroys the membrane of the red blood cells with the liberation of haemoglobin, cataracts, headache, confusion, excitement, malaise, performance, profuse sweating, nausea vomiting, abdominal pain, irritation of bladder. Its volume of acceptable daily intake is $0.096 \mathrm{ug} / \mathrm{m}$

- $\quad$ According to the Sierra Club report "Unhealthy Effects of Upstream Oil and Gas Flaring," gas flares in Alberta, Canada are associated with increased risk of dermatological problems, spontaneous abortion and numerous kinds of cancer. The gas that is burnt through tall pipes at oil production sites disperses its pollutants over wide areas, and these pollutants can cause damage to humans at concentrations that are far below what can be detected by smell. In other words, the health risks are not detectable by sufferers until the damage is done. As of 1996, there were 6,500 flares in 1,410 townships in Alberta alone (Argo, 2001)

- $\quad$ According to the United States Energy Association, somewhere between 150 and 200 billion cubic meters of natural gas are burned off in gas flares worldwide every year. The same organization estimates that, if the gas that is flared in Africa alone were captured and used to create electricity, it could provide 50 percent of all the electricity used in Africa (United States Energy Association- undated). By burning this gas in an uncontrolled manner rather than converting it to useful power, oil producers are contributing to the growing problem of climate change by releasing potent greenhouse gases into the atmosphere. Thereby causing acid rain which destroys not only roofs of buildings but also the human skin and valuable crops meant for human consumption.

- $\quad$ The presence of carbon and traces of nitrogen and sulphur in natural gas leads to the production of various oxides and sulphides, when these chemicals are inhaled through the flaring it settles in nostrils down to the lungs as thick carbon monoxide, which blocks the passage of oxygenated blood to the heart of human beings and animals. The oxides and sulphides in hydrocarbon with gaseous chemicals when flared combine with water in the atmosphere to form various types of corrosive acids such as nitric and sulphurous acids that irritates the human skin and prevent plants chlorophyll from functioning (Nigerian Compass, 2012).

The flares contribute to acidic rain and villagers complain of the rain corroding their buildings. The particles from the flares fill the air, covering everything with a fine layer of soot. Residents of communities close to the flares also complain about roaring noise and the intense heat from the flares. They live and work alongside the flares with no protection.

\section{"Strange Black Soot": A Contemporary Rivers State Experience}

The World Bank underscoring the nature of Nigeria's environmental challenges in 2015 stated that $94 \%$ of Nigerians were exposed to air pollution levels that exceed World Health Organization (WHO) guidelines. Nothing buttresses this fact more than the prevailing situation of Rivers State. It is now common knowledge that since late November 2017, strange black soot has been falling from the sky scaring residents of Port Harcourt city and neighbouring Local Government Areas such as Eleme, Oyigbo, Ikwere, Obio/Akpor, Kahna, Gokana, and Tai. The clouds became hazy and grey. If you hang your cloths before you know it, they have become black. Even in the house, if you step on the floor, your foot will be black. Traders have to cover their wares with umbrella of different sizes and shapes, just as residents began to wear protective face mask. The soot is most pronounced in the morning hours. The Rivers State government reacted by setting up a task force to investigate the matter while the Federal Ministry of Environment declared the air pollution an "emergency situation" and warned residents to shut their doors and windows.

The ranking of Port Harcourt as the world's most populated city in the world accentuated state of panic among residents and forced the wealthy elite to and those who have alternative homes are relocating from the city. Similarly, in April 2018, air visual ranked Port Harcourt as the worst polluted in the world with an index of 188, followed by Beijing, China which ranked 182 and Delhi, India at 181 among others. Close monitoring of showed that the index of Port Harcourt has increased from 188 to 200 and above since April 2018 (Godwin, 2018). This 
situation is very worrisome.

Results of preliminary samples showed that the soot was caused by "incomplete combustion of hydrocarbons as well as asphalt processing and illegal artisanal refining operations. Air quality is worsened by the use of generators to make up for the gaps in supply from the national electricity grid as well as petrol containing sulphur. Toxic smoke also comes from the burning of rubbish- a legacy of the absence of efficient municipal waste management services. Consequently, the Task Force on Black Soot set up by the State Government to investigate and resolve the environmental challenge closed down three companies operating in the state. The affected companies are Chinese Government Company (CGC), HSH Engineering Company and AUC Asphalt Company for allegedly operating machines that emit high magnitude of hydrocarbon into the atmosphere. The asphalt was found to be producing thick black smog out of the furnace in the processing of asphalt, heavily polluting the air (Iheamnachor, 2017). Doctors in the medical institutions in Port Harcourt said the soot is affecting the health of residents as shown with increase in consultations for breathing difficulties, including asthma. Similarly, environmentalists are also sounding the alarm because the soot has been found to contain sulphur dioxide and nitrogen dioxide, which cause acidic rain when combine with moisture.

The Niger Delta operational environment encourages oil theft because the oil and gas infrastructure are located onshore or in in the swamps and shallow waters- where oil pipelines crisscross in the grid-like pattern linking the area's twenty-two petroleum storage depots and four refineries most frequently targeted by oil thieves in tapping operations. To an un-careful outsider, the oil theft economy appears chaotic; the point of fact is that there is a structure to this illicit business. Given the finite number of locations where it can easily be done and competition between groups involved, this economy is quite organized. Oil theft is a lucrative business implicated in the region's environmental challenges. Crude oil produced in the state like other states in the Niger Delta region are stolen in several ways. First there is the theft associated with ethnic militia forces whereby militia provide security cover for illegal oil cartels who steal large volumes of crude oil directly from pipelines. The crude is taken from well heads where the oil is diverted to a barge which tranships the oil to a tanker standing by ready to ship the crude overseas. The second method is known as "hot tapping" where oil thieves breach a pipeline at night with the result that the oil company shuts down the flow line which allows the thieves excavate the pipeline some distance away and install a tap through which they deliver a constant supply of oil to their own facilities. The third is a smaller scale theft where local small scale operators tap petroleum product lines and sell the product on the local market (Davis, 2008). Although the activities of artisanal refineries in Rivers State may appear small compared to some core Niger Delta States, their environmental impacts and ripples pervade the immediate areas of operations and beyond.

This rouge economy thrives on involvement of criminally minded company officials or former oil companies' employees. For example, hot tapping, requires critical technical information/advice which can only be provided by company insiders or former employees with good technical knowledge and critical information such as vulnerable pipelines and the expertise required to lay taps effectively for the operation as well as the security architecture of International Oil Companies. It is also alleged that oil company workers who occupy positions in pipeline control rooms are paid to lower the pressure in the pipelines to prevent them from exploding when taps are placed. Similarly, operators of this illicit business alleged that the control room operators are paid as high as $\$ 4,500$ for reducing pipeline pressure or informing oil thieves when pressure will be reduced for routine maintenance operations.

Unfortunately, artisanal refining of stolen crude in the Region is justified by perpetrators as a backdoor resource control which a few community members have had the courage to participate in. Some of the beneficiaries of illegal oil bunkering and artisanal refineries are now wealthy and enjoy popularity amongst the poor and uninformed community people, who unfortunately are a big minority in the State. Little wonder Davis (2008) argues forcefully that the success on the basis of community participation in the fight against oil theft must be tied to community participation in the management of oil activities and the benefits derived therefrom.

Oil thieves are further encouraged by the inability of the government to build and run domestic refineries. For example, the current refining capacity of the four refineries in Nigeria is 445,000 barrels per day (bpd). At full capacity, these refineries can only meet about sixty percent (60\%) of Premium Motor Spirit (PMS) domestic demand. For over two and half decades, the refineries have at best functioned at forty percent (40\%) capacity due to mismanagement in the downstream sector, lack of Mandatory Turn Around Maintenance, corruption and sabotage by officials. Consequently, over ninety percent (90\%) of PMS consumed locally is imported, while the refineries remain largely idle and operate at substantial loss to the country (Hart group, 2009; Joab-Peterside, 2010; 2012).

Employment in the region's remote areas includes traditional occupations such as fishing and farming, as well as small-scale trading. Opportunities for engaging in these activities are limited given environmental degradation and lack of credit or business start-up support. When coupled with lack of investment in the region, over all poverty, corruption as well as the glaring cases of limited capacity to benefit legitimately from oil activities, the stage is set for chronic youth unemployment. Thus unemployment among the youth is an issue with a number 
of important consequences for oil theft and illegal refineries and other forms of violent economic activities.

The failure of the government and the oil industry to ensure that the people of the Niger Delta benefit from the oil wealth created frustrations and grievances that have built up over decades of neglect that culminated first in peaceful political protests but later, in attacks on oil and gas infrastructure and personal. Oil companies' staffers were routinely abducted for ransom and sabotage, just as forced occupation of oil installations became the order of the day. While the attack on Oil Company personnel grew the theft of oil and illegal bunkering by well-armed criminal gangs became lucrative and wide spread. Obvious lack of social infrastructure provisioning, failure to address the comprehensive the root causes of the development problematic allows this trade to flourish.

On a broad canvas, oil theft and artisanal refining can be located at the door step of absence of good governance frameworks at all levels (federal, state and local government) which can effectively strengthen the use of political power and resources. Good governance means creating well-functioning and accountable institutionspolitical, judicial and administrative- which citizens regard as legitimate, in which they participate in decisions that affect their daily lives and by which they are empowered (Annan, 1998). When the principle of governance is undermined, it precipitates opposition, alienation, resistance and disillusionment. In the past four decades, social sectors have suffered a lot from economic reforms. This has contributed to worsening of social indicators, including declining school enrolment rates, increase in under five mortality rates, increasing child labour, declining immunization coverage and increase of child malnutrition rates. These symptoms of bad governance have allowed for the germination of violent behaviours such as oil theft and restiveness, which in turn has discouraged investment, deprived the Niger Delta of enormous public-private resources for development.

It is noted here that the chaotic state of infrastructural development and pervasive corruption account for why the area's huge oil and gas endowment is a very strong thread of attraction and contention between various interests. There is no doubt that some oil theft and refining activities occur simply for the enrichment of the perpetrators. In some cases, oil theft activities take place out of necessity, particularly in situation of poverty. This is often the case with small scale oil thieves. Where corruption pervades, people can be drawn into oil theft activities as it represents the mainstream of the society they dwell (Davis, 2008). The makeshift refineries have created environmental and health problem for the people because the environment is being destroyed daily through oil spillage and disposal of waste from crude refining across the creeks and waterways. The degradation of the environment from pollution of running waters to rivers and destruction of farm land is monumental and catastrophic. The oil theft economy has also created a new class of business elites in the communities and the distortion of the value system. In order to control locations, oil thieves often actively support lenient community leaders especially chiefs, with cash and thugs and oppose or kill community people who resist their activities. In addition, the process of social disintegration is fuelled by youths involved in oil theft, who empowered by cash and weapons, challenge legitimate community leadership. Corruption is endemic while fights over control of oil theft turf often feed into inter and intra-community fights resulting in high level of violence.

Apart from oil and petrochemical industry in the region, the level of industrialization in the Niger Delta can be described as moderate. Industrial activities are mainly concentrated in the State capitals and major centres. This is particularly the case in Rivers State where the major industries are located in Port Harcourt (Trans Amadi axis). The dominant medium and large scale industries (excluding petroleum and petro-chemistry) are food processing, wood products, metallurgy, synthetic fibres and plastic, rubber, cement and steel. The low levels of industrialization in the rural areas of the region confine environmental degradation from industries to local scale. This implies that industrial pollution is not a region wide threat. The region also hosts two of the three operating refineries in Nigeria. Specifically, the two refineries are located at Warri and Port Harcourt. The Port Harcourt refinery as at 1998 was estimated to produce over ninety percent of the hazardous sludge generated in Port Harcourt. The ability of the refinery to manage the hazardous sludge is not public knowledge. Worse still, the sludge from the refinery at Warri was for some years disposed of in a neighbouring swamp. The National Fertilizer Company of Nigeria (NAFCON) now known as IDORAMA located at Onne near Port Harcourt is one of the Two Nitrogen plants in the country. Effluent-treatment systems were reported to function only intermittently (Moffat and Linden, 1995). Consequently, communities near the facility have complained of chocking gases coming from the plant, which could be from Nitrogen compound releases. Some residents reported that the situation has changed though, not completely. Let us at this juncture turn the search light on the case of Ogoni ethnic nationality to draw attention to the intensity of contemporary environmental challenges as a microcosm of the Niger Delta situation.

\section{The Ogoni Case}

According to UNEP (2011), oil contamination in Ogoniland is widespread and severely impacting many components of the environment. Although the oil industry is no longer active in the area, oil spills continue to occur with alarming regularity. In fact, Ogoni people live with this pollution every day. As a result of high rate of rainfall, any delay in cleaning up oil spills leads to oil being washed away with implications for farmland and almost always ending in the creeks. At one site, Ejama-Ebubu in Eleme LGA, the study found heavy contamination present 40 years after an oil spill occurred, despite repeated clean-up attempts. 
Pollution of soil by petroleum hydrocarbons in Ogoniland is extensive in land areas, sediments and swamplands. Most of the contamination is from crude oil although contamination by refined product was found at locations. The absence of continuous clay layer across Ogoniland exposed the groundwater in Ogoniland (and beyond) to hydrocarbon spilled on the surface. Oil pollution in many intertidal creeks has left mangrove denuded of leaves and stems, leaving root coated in a bitumen-like substance sometimes $1 \mathrm{~cm}$ or more thick. Mangroves are spawning areas for fish and nurseries for juvenile fish and the extensive pollution of these areas is impacting the fish life-cycle. Any crops in areas directly impacted by oil spills will be damaged, and root crops, such as cassava, will become unusable. When farming recommences, plants generally show signs of stress and yields are reportedly lower than in non-impacted areas.

Surface water throughout the creeks contains hydrocarbons. Floating layers of oil vary from the thick black oil to thin sheets. The highest reading of dissolved hydrocarbon in the water was detected at Ataba-Otokroma, bordering the Gokana and Andoni LGAs. Fish tend to leave the polluted areas in search of cleaner water, and fishermen must therefore also move to less contaminated areas in search of fish. When encountered in known polluted areas, fishermen reported that they were going to fishing grounds further upstream or downstream. Despite community concerns about the quality of fish, results show that the accumulation of hydrocarbons in fish is not a serious health issue in Ogoniland but that the fisheries sector is suffering due to the destruction of fish habitat in the mangroves and highly persistent contamination of many of the creeks, making them unsuitable for fishing. Where a number of entrepreneurs has set up fish farm close to the creeks, their business has been ruined by everpresent layer of floating oil. The wetlands around Ogoniland are highly degraded and facing disintegration (UNEP, 2011).

While it is technically feasible to restore effective ecosystem functioning of the wetlands, this will only be possible if technical and political initiates are undertaken. The Ogoni community is exposed to petroleum hydrocarbons in outdoor air and drinking water, sometimes at elevated concentrations. They are also exposed through dermal contacts from contaminated soil, sediments and surface water. Since life expectancy in Nigeria is less than 50 years, it is a fair assumption that most members of the current Ogoniland community have lived with chronic oil pollution throughout their lives (UNEP, 2011).

Although there is now a decline in pipeline vandalization due to military onslaught, oil theft posse serious threat to the environment. It in recognition of this threat that the UNEP report recommended that a campaign in Ogoniland to end illegal oil-related activities should be jointly conducted by government, oil companies and local authorities. This campaign should include an awareness component highlighting the disproportionate environmental footprint of artisanal refining (borne by all sections of the community) and spell out training, employment and livelihood incentives that will encourage people away from participating in this illegal activity (UNEP, 2011).

Management of Municipal Solid Wastes: solid waste management it appears is the most pressing environmental challenge faced by urban and rural areas in the region and with population explosion of the major cities, the problem of solid waste management is assuming alarming proportions. Most of the waste is generated by households and in some cases, by local industries, artisans and traders which litters the immediate surroundings. In fact, improper collection and disposal of municipal wastes is leading to an environmental catastrophe due to the serious health threat it poses to people living in urban areas and some rural communities. Solid wastes are present everywhere clogging drainage systems and increasing and increasing flooding and water related diseases. The Municipal solid-waste in Port Harcourt is in an order of magnitude higher than industrial solid-waste generation. The incidence of typhoid, malaria fever etc. attacks among urban residents can be largely attributed largely to the deterioration of their immediate environment. Part of the problem derives from rapid urbanization and associated inadequate infrastructural facilities to serve the growing population (Efe, 2013).

In Uyo, Port Harcourt and Ughelli (Delta State) solid waste are collected in bins that are located along major streets or receptacles (Efe, 2013, Okey et al, 2013). Different types of vehicles are employed to transfer waste to dump sites. These include compactor trucks, tippers, pick-ups, side and rear loader and skip trucks. It is pertinent to note that often times these vehicles are in a state of disrepair and broken down. The efficiency of collection is quite low with less than fifty per cent of generated solid waste actually conveyed to dump sites. Worse still, the collection time is also irregular, consequently waste accumulate in open dumps at road sides when the bins are full. Most of the dump sites and often filled and overflow. Like most government business, the collection, transfer and utilization of waste is grossly inadequate. Okey et al., (2013) and Efe (2013) traced the problem to poor funding, lack of expertise and manpower, use of obsolete technology as well as lack of data. In most cities in the region, there is no formal recycling of waste materials. Hence, recovery functions are carried out by informal sectors such the scavengers who manually sort out garbage and recover only limited items such as plastics. Yet recovery is more environmentally friendly because it not only reduces the amount of waste to be collected and transferred but also generates income for government and individuals. Away from the state capital and the Local Government Areas(LGAs) hosting the capitals, most LGAs do not have a proper waste management that cuts across the nook and crannies of the states, thus most towns in the region resort to waste burning. 
Similarly, municipal sewage is not properly collected and disposed of anywhere in the Niger Delta. Consequently, households, commercial establishments, and industries discharge waste directly into open drains. Many of the drains are unlined, blocked with solid wastes, or broken. Organic pollutants levels in surface and ground water especially, in Port Harcourt are extremely high. Apart from phosphorous, which is generated by the fertilizer plant at Onne near Port Harcourt, domestic and small-scale industry sources of eutrophying components are significantly higher percentage of total discharges than industrial sources. These high levels no doubt, represent a considerable health hazard to majority of the population who rely on surface and shallow groundwater supplies for drinking and cleaning (Ayotamuno and Akor, 1994; Moffat and Linden, 9195). The next section focuses on selected responses of government to the environmental problematic.

\section{Government's Response}

Land use and oil production activities in the Nigerian state are governed by a number of obnoxious laws perceived as instruments of dispossession which result in resource predation and associated environmental tragedies. Facts at the disposal of this paper indicate the existence of over twenty-five (25) major environmental laws in the country. These include the Oil Pipelines Act (OPA) 1956 (amended in 1965) only provides compensation for spills due to pipelines ancillary installation ruptures; Oil in Navigable Waters Acts (ONWA, 1968); Petroleum Acts(1969); Associated Gas Re-injection Act (AGRA, 1979); the Federal Environmental Protection Agency (FEPA) Act (1988); the National Policy on the Environment, 1989(revised in 1999); National Environmental Protection(Effluent Limitations) Regulations (1999); Environmental Protection(Pollution Abatement in Industries Generating Wastes) Regulations (1991); Environmental Impact Assessment (EIA) Act(1992); and Department of Petroleum Resources (DPR) Environmental Guidelines and Standard for the Petroleum Industry in Nigeria (EGASPIN) (2000)(62).

Regrettably none of these laws are fully implemented by the relevant agencies because existing institutions in the Niger Delta are either inactive or busy duplicating efforts, while the legal situations have been considered inequitable. Hence a major thread in community disturbances. Despite the official pronouncement of the oil majors on international best practices in terms of environmental consciousness their areas of operation, some officials in the Environment Department admitted privately that there is a huge gap between what they recommend and what engineers chose to do in the field.

The critical sections of the Land Use Act for Rivers State like any other core Niger Delta state, include sections 1, 28 and 29. Section 1 states that "all land comprised in the territory of each state in the Federation are hereby vested in the Governor of the State and such land shall be held in trust and administered for the use and common benefit of all Nigerians in accordance with the provisions of this Act". Section 28 which deals with the power of the Governor to revoke rights of occupancy for "overriding public interest" defines such public interest to include section $28(2)(\mathrm{c})$ and (3)(d) "requirement of the land for mining purposes or oil pipelines or for any purpose connected therewith. A full definition of "public interest" is provided in Section 51(1) a-i.

Most worrisome, is the seeming inability of government to implement comprehensively the Eight Emergency Measures recommended in the 2011 UNEP Report, which from a duty of care point of view, warrant immediate action. These emergency measures are:

- $\quad$ Ensure that all drinking water wells where hydrocarbons were detected are marked and that people are informed of the danger.

- $\quad$ Provide adequate sources of drinking water to those households whose drinking water supply is impacted.

- $\quad$ People in Nsisikoken-Ogale who have been consuming water with benzene over 900 times the WHO guideline are recorded on medical registry and their health status assessed and followed up.

- Initiate a survey of all drinking water wells around those wells where hydrocarbons were observed and arrange measures (1-3) as appropriate based on the results.

- $\quad$ Post signs around all sites identified as having contamination exceeding intervention values warning the community to walk through or engage in any other activities at these sites.

- $\quad$ Post signs in areas where hydrocarbons were observed on surface water warning people not to fish, swim or bathe in these areas.

- Inform all families whose rainwater samples tested positive for hydrocarbons and advise them not to consume the water, and

- Mount a public awareness campaign to warn individuals who are undertaking artisanal refining that such activity are damaging their health (UNEP, 2011:13).

In some communities where rivers and tributaries were polluted, there were no signpost warning locals against the use of the water. In Gokana Local Government Area, communities like Bodo city, Goi, B-Dere, K-Dere, Deken and Lewe, there sing posts around impacted sites and polluted water resources. However, some locals, including children often times bathe in the polluted water despite the existence of warning signs for lack of alternatives (Fyneface \& Akhigbe 2014).

We must emphasize environmental regeneration and sustainable resource use to ensure food security, water, 
waste/pollution, disaster and coastal zone management, protection of pristine sites, biodiversity, land-use and landcover change, energy and industrial transformation. One of tragedies of the Niger Delta is that in extracting oil and gas, which are finite, non -renewable resources, we are destroying renewable resources such as forests and natural acquirers.

Government's intervention to douse tension in the region and check the menace of oil theft and refining include creation of special security forces such as Operation Fire for Fire; Operation Restore Hope; Operation Salvage; Operation Pulo Shield with the mandate to stamp out oil theft and illegal refining business prevalent in the region. Pulo is an Ijaw wording meaning oil. "Operation Safe Delta" and "Operation Crocodile Smile 1 and 11 ", which is a military exercise that involves amphibious war games in the Niger Delta region and part of Ogun State with the mandate to protect the nation's crude oil infrastructure. "Operation Tsera Teku" was officially launched in Warri Delta State in February, 2018 to check piracy in the Niger Delta region. The operation was expected to curtail pipeline vandalism, armed robbery and other offshore and around the creeks criminality. It also aimed at protecting ships and oil and gas installations. "Operation Delta Safe" was set up to replace Operation Pulo Shield with the aim of containing security challenges in the Niger Delta, especially protection of critical national assets and provision of security in the area.

The scale of oil theft and refining suggests that senior state officials protect and backed armed oil thieves to enable the latter to continue to continue small scale oil theft and provide security services to large scale illegal bunkering cartels without interference by state security forces. In fact, those running this rough economy at the top are apparently untouchable. Members of these security outfits and state security forces have been accused of involvement in the lucrative illegal oil business, which include a relatively sophisticated level of theft and refining. But state security authority had denied involvement in the economy of violence. The Joint Task Force (JTF) policing the Niger Delta claimed it destroyed 6,000 illegal refineries across the mangrove swamps of the Delta in 2011. Sadly, only about thirty per cent $(30 \%)$ of the refined oil was recuperated while the remaining seventy percent $(70 \%)$ was discarded into the environment thereby compounding the woes of the already fragile environment (Vanguard, 2017).The federal government has commenced equipping the Navy to adequately patrol the shorelines where pipelines are located. In addition to that, the Nigerian Navy recently launched a website dedicated to tracking oil thieves and their activities. Government also empowered the police, army and Nigerian Security and Civil Defence Corps (NSCDC) to patrol areas where pipelines and other oil facilities are located by providing them with needed equipment and vehicles.

\section{Exploring Strategic Options}

There is a long and terrible record of environmental degradation and human rights violations in the Niger Delta. I have stated somewhere earlier in this paper that the gross level of environmental degradation caused by oil exploration and production activities has gone on unchecked for over four decades. The multinational oil companies operating in the region have not only disregarded their responsibility towards the environment, but they have also failed to provide infrastructural facilities and employment for the army of unemployed youths in their host communities.

The oil bearing ethnic nationalities in the Niger Delta, have long demanded a direct stake in the oil revenues derived from their area as a means of curtailing violent conflicts, reverse oil's legacy of decline and allow for stable energy production. This demand is contained in several bills and declarations of the ethnic nationalities. Success in fight against oil theft must be tied to community participation in the management of oil activities and the benefits therefrom. The Ministry of Petroleum as far back as 2010 stated that "host community participation in ownership of petroleum assets in oil producing countries has proven globally as the antidote to violence and militancy" (Transnational Crisis Project, 2010). Equity participation is one sure way the oil bearing communitiesthe most affected by land degradation, and increasing pollution related illness associated with oil exploration activities will benefit the more from enormous wealth derived from oil; and motivated to protect facilities located on their land. This implies that while the state retains ownership of the resource (oil) in question, but grants some special access rights and management responsibilities to the concerned communities. The innovative feature of equity participation is the understanding of the advantages of going beyond strict legal jurisdiction characterized by dispossessions and recognizing the entitlements of ethnic nationalities and other concerned groups. This recognition of community rights and interests will mark a significant departure from legalistic top-down management model.

The rural economies of the communities are dying because of their dislocation by the petro-economy. It is part of Nigeria's paradox that the sector which in other climes grows viable communities, is the one implicated in the gradual decay of these communities in the country. No doubt, the contributions of the oil majors towards development have been helpful but not so much as envisaged by inhabitants. Although some of the companies' development programmes are usually heavy on so called "community development projects", curiously enough, they have not developed any community in a true sense. Consequently, the ethnic nationalities have long demanded a stake in the oil revenues derived from their area. This demand is contained in several bills and declarations of 
the ethnic nationalities as shown earlier.

As if to aced to request of the people for equity participation, in October 2009 the federal government responded when the President Umaru Muaa Yar'adua announced that Niger Delta communities are to receive a ten percent $(10 \%)$ "royalty" of selected national oil profits. This proposal which was intended to cover all the existing and currently operating Joint Ventures was perceived as the "antidote to violence" in the region. Government intended to scale down the equities which it currently holds through the NNPC in the respective Joint Ventures. In order to retain $41 \%$ equity position in the Joint Ventures (JVs), government intends to sell down 14\% in SPDC JV and $19 \%$ in the other JV respectively.

This presidential proposal was both heartening and not. The challenges of this initiative include how to calculate the proposed ten per cent $(10 \%)$ and definition of oil producing communities (will communities be included in the royalty based on their proximities to oil and gas reserves, oil infrastructure or access route), how many trusts will there be, and how will the boundaries be drawn (Sayne, 2010). What about the capacity of indigenous governance systems to cope with the mechanism of funding of the equity for the host communities, and preparedness and speed of state legislatures to pass a law establishing a host communities Permanent Fund Corporation to manage the assets of the Fund without pitching members of the communities against themselves. Current effort resurrected the Host-Community Trust Fund framework. As if the oil bearing communities do not matter, government is interested first in the Petroleum Industry Governance Bill (PIGB) which had already be passed on to the President for assent, as usual, the Host Community Bill will follow later.

Oil has seeped deeply and indelibly into the political economy of Nigeria and into the national psyche and social imaginary epitomized by a dual politics of dispossession and resentment. First, is the capture of oil rents by the state through plethora of obnoxious legal regimes which resulted in conversion of oil into a national resource in the face of robust traditions of customary rule and land rights, and ethnolinguistic rule construed locally as expropriation and dispossession. The several demands and petitions from ethnic nationalities and communities in the Region all acknowledged this profound expropriation and loss. Some of these petitions include the following: The Ogoni Bill of Rights, 1990; The Charter of Demand of the Ogbia People, 1992; The Kaiama Declaration, 1998; Resolution of the first Urhobo Economic Summit, 1998; The Akalaka Declaration, 1999; The Warri Acord, 1999; The Ikwere Rescue Charter, 1999; First Niger Delta Indigenous Women Conference, 1999; The Oron Bill of Rights, 1999; and the Niger Delta Peoples' Compact, 2008. These claims which were inevitably expressed in ethnic terms ("our land; "our oil) marked the emergence of oil producing minorities not only as a political category but as an entity with strong territorial claims (RTCN, 2008; Watts, 2015).

Oil thieves are further encouraged by the inability of the government to build and run domestic refineries. For example, the current refining capacity of the four refineries in Nigeria is 445,000 barrels per day (bpd). At full capacity, these refineries can only meet about sixty percent $(60 \%)$ of Premium Motor Spirit (PMS) domestic demand. For over two and half decades, the refineries have at best functioned at forty percent (40\%) capacity due to mismanagement in the downstream sector, lack of Mandatory Turn Around Maintenance, corruption and sabotage by officials. Consequently, over ninety percent (90\%) of PMS consumed locally is imported, while the refineries remain largely idle and operate at substantial loss to the country (Joab-Peterside2010; Joab-Peterside, 2012).

Employment in the region's remote areas includes traditional occupations such as fishing and farming, as well as small-scale trading. Opportunities for engaging in these activities are limited given environmental degradation and lack of credit or business start-up support. When coupled with lack of investment in the state, over all poverty, corruption as well as the glaring cases of limited capacity to benefit legitimately from oil activities, the stage is set for chronic youth unemployment. Thus, unemployment among the youth is an issue with a number of important consequences for oil theft and illegal refineries and other forms of violent economic activities.

Solving the problem of unemployment is essential. This entails creating opportunities and encouraging independent initiatives of Niger Delta people and communities. We have shown that oil theft and refining provide employment opportunities for some people in an area ironically reputed for its poverty than opulence. Against this backdrop, a creative transformation of the "make shift" refineries could provide further employment for inhabitants of affected communities and redirect their energy away from social vices which pose threat to national security to more productive ventures. This also possesses the potential to curb crude oil theft and allow for a formalized supply for refining purposes.

An aggressive public enlightenment campaigns on the short and long-term socio-economic consequences of oil theft and artisanal refining is crucial preliminary step. Creation of collaborative arrangements through StateCivil Society-Community synergies possesses the potential for improved policy outcomes. A strong civil society, especially free and pluralistic medium of communication, consultative processes and other forum necessary to ensure participation in socio-political and environmental management, and the urgent need for Rivers State government to conduct and environmental audit in all the oil bearing communities to the extent and consequences of the environmental challenges and implementation framework.

While a holistic approach to the environmental challenge is desirable, Popoola's (2017) recommendation of 
five ways to temporarily check the black soot problem is implementable, hence attractive. Summary of the temporary checks are as follows:

(1). General cleaning: surfaces should be cleaned daily with detergent in order to avoid the accumulation of soot. Doing this regularly would reduce the amount of black soot gathered around the house and offices.

(2). Shut windows: windows should be shut as often as possible in order to prevent the soot from filtering in. also minimize the contact you have with open spaces in order not to let your hands touch the soot.

(3). Use nose mask: wearing a nose mask in this period will prevent you from inhaling the contaminated air; soot will be prevented from getting in to the nasal cavity when a mask is being worn.

(4). Wash your hands daily: your hands may have gathered germs and might have touched the open surface filled with the soot. It is advisable for residents to take shower three times daily.

(5). Keep your skin covered: Protective clothing will help many residents at this period when the city and its environs are covered with soot. The air vents should be dusted from time to time. Eating foods that are not exposed is not healthy as they could have been contaminated.

Government of the Niger Delta states should as a matter of urgency revive its solid waste management framework to make it attractive for private sector to invest in waste collection, recycling and reusing. Consequently, the Environmental Health Officers Registration Council of Nigeria needs to intensify effort to monitor and enforce sanitation laws as well as regulate the activities of the franchisees on good sustainable practices. Government and the Civil Society take the advocacy further on waste management to check littering the environment. It is gratifying to note that some manufacturing companies such as chemical and plant industry have introduced a recall process that will reward individuals who return empty/used plastic containers. This cash incentive has proved overtime to validate the waste to wealth programme embarked upon by the manufacturing companies.

State governments should be encouraged to build compositing and recycling plants in addition because most of the available solid waste management services are often over stretched due in part, to population explosion and lack of awareness on the general public on management of waste from domestic and commercial sources. It is therefore not a surprise that roads and streets in the major cities are littered with solid wastes. This implies that to a large extent, the major cause of poor environmental sanitation in some states in the region, relates to poor administrative management and the lack of inappropriate technology (Efe, 2013). Municipal waste management is a big challenge for state government agencies to manage alone hence, the need to engage the services of private firms with the requisite technology and other franchises to reduce the burden of waste collection and disposal.

\section{Conclusion and Recommendations}

The oil industry is the most important sector in the Niger Delta economy; other industries play a minor role only. Unfortunately, the oil industry culture seems to be founded on the assumptions that profit maximization is the only basis upon which a company can be run, so that any expenditure beyond what is required to get out oil such as that on environmental protection is resisted;and that an agreement has been reached with the managers of the Nigerian state, an oil company can do what it likes, in fact, it can act as if it an agency of the state. Associated with oil related environmental challenges is the phenomenon of oil theft energized by lack of legitimate supplies, expose both operators and other community members to unimaginable health and environmental risks; inappropriate solid waste management framework, obsolete/absence of contemporary technology as well as good governance. Facts at the disposal of the paper show that the environmental challenges have affected the fragile ecosystems and impacted even more fundamentally on the socio-economic conditions and life chances of Niger Delta residents.

The plethora of laws on environmental management is observed more in the breach. Hence, there is need for faithful adherence to and enforcement of the environmental laws and standards. There is no alternative to sound environmental assessment, good environmental counting and auditing. Besides adopting a form of tax embedded in the concept of Polluter-Pays-Principles in order to limit environmental degradation, in line with global thinking on sustainability, the concept of Sustainable Net National Profit (SNNP) must be adopted in which actual production profit is less environmental cost of production. It is important to stress that prevailing state of environmental degradation is not all about oil and gas activities as the region is unable to manage rudimentary and routine environmental consequences of development activities and urbanization. This is not only reflective of environmental concerns but much fundamentally, a deep-seated environmental management system failure and indiscipline.

Furthermore, a deep sense of alienation from oil resource revenue pervades the oil bearing communities; hence there is an urgent need to develop a sense of direct involvement and ownership in oil and gas activities amongst communities. I contend, that a true partnership and stake-holding that guarantee protection of oil and gas installations and by extension, the environment lies in each community around whose land oil and gas activities are taking place to be allotted equity holding in the Industry as Joint Venture Partners, proceed from which can be invested in infrastructural development, generate economic activities, create employment and wealth. Oil companies operating in the Niger Delta are obliged to adopt all practical and internationally acceptable precautions including provision of up-to-date equipment to prevent pollution and should take prompt steps to control and if 
possible, end pollution when it occurs. Finally, it is common knowledge that most of the facilities in the region are in dire need of upgrading as most of them were constructed in the 1960s and 1980s; while state governments should walk the talk for effective municipal waste management and environmental audit.

\section{References}

Abam, T. K. S. 1995. State of Erosion and Flooding in the Niger Delta. Report Presented for the World Bank

Akujuru, V. 1992. The Professional Duty of the valuer in oil pollution compensation valuation. Paper presented at the NIESV $22^{\text {nd }}$ Annual Conference, Port Harcourt.

Amakiri, A. 1997. Damage Assessment following oil spill at orubiri oil field, Okrika, Professional Valuation Report 5 (Remani-Abah Associates).

Amnesty International 2005, Nigeria Ten Years On: Injustice and Violence haunt the oil Delta

Aina, E. O. A. 1996. Towards Environmentally Sustainable Development in the Petroleum Industry in: E. O. A. Aina and N. O. Adedipe(eds). The Petroleum Industry and Environmental Impact in Nigeria Abuja, Federal Environmental Protection Agency, FEPA Monograph.

Aprioku, I. M. 1996. Democratization and Socialization of Power in Nigeria: The Case of Urban Management in Port Harcourt City. Urban Management Forum for Port Harcourt Municipality, March (Port Harcourt.)

Aprioku I. M. \& Bereweriso, I. O. F. 1996. Environmental Health Hazards and Accidents: Experience from rural Rivers State, Nigeria. Paper presented at the EBan Conference, November (Ekpoma).

Aprioku, I. M. 1999. Collective Response to Oil Spill Hazards in the Eastern Niger Delta of Nigeria. Journal of Environmental Planning \& Management, May, Vol. 42 Issue 3, p389.

Argo, J. 2001. Unhealthy effects of upstream oil and gas flaring. Sierra club.

Ayotamuno, M. J and Akor, A. J. 1994. The Pollution Potentials of open drains in Port Harcourt. Nigeria Environ. Mgt. health 5, 28-32.

Brown, B. S. 2004. Address by the President, Nigerian Institute of Public Relations(NIPR), at the Oil and Gas Syndicate Session of the 2004 FAPRA, Abuja Conference on May $24^{\text {th }}, 2004$.

Brown, J. 2006. Niger Delta bears brunt after 50 years of oil spills, Independent, 26 October; also see WWF-UK and CEESP-IUN Commission on Environmental, Economic and Social Policy.

Centre for Environment, Human Rights and Development(CEHRD), 2008. Persistent oil spillage at Bodo Creek, October, www.cehrd.org.

Clean the Niger Delta. 2010. Powered by Joomla info@cleanthenigerdelta.org.

Chokor, B. A. 2006. The Environmental Consequences of the Oil and Gas Industry in the Niger Delta. Paper Presented at the Conference on Democracy, Security and Development: Implications for the Oil and Gas Industry in the Niger Delta, Organized by the Nigerian Institute of International Affairs, Lagos and the Centre for Advanced Social Sciences, Port Harcourt, $31^{\text {st }}$ July-3 ${ }^{\text {rd }}$ August, 2003.

Davis, S. 2008. Robbery Figures for Oil Theft in the Niger Delta. Legal-oil.com. information Paper No. 4.

Dulue, C., \& Nwankwo, C. 2001. Land, Oil and Human Rights in the Niger Delta. Niger Delta Channel, January. Great Creeks Media LTD, Port Harcourt.

Efe, S. I. 2013, Waste Disposal Problem and Management in Ughelli, Nigeria. Journal of Environmental Protection, 2013, 4, 4-11. http://dx.doi.org/10,4236/jep.2013.44A002. published online April 2013(http://www.scrip.org/journal/jep).

Friends of the Earth Netherlands, Shell, clean up your mess in Nigeria www.milieudefensie.nl/globalisering/doemee/earthalarmee/ae109_engels_shell

Fyneface, F. D. and Akhigbe, L. 2014. Still Polluted: Monitoring Government and SHELL's Responses to UNEP's Environmental Assessment of Ogoniland. Social Development Integrated Centre (Social Action), Port Harcourt.

Godwin, A. 2018. Port Harcourt: Anger, Anxiety as soot takes over skyline, environs. The Guardian. $6^{\text {th }}$ may. www.guardian.ng/sunday-magazine/port-harcourt-anger-anxiety-as-soot-takes-over-skyline-environs

Human Rights Watch, 1999. The Price of Oil. Corporate Responsibility and Human Rights Violation in Nigeria's Oil Producing Communities. New York. Washington. London. Brussels.

Ibe, A. C. and Awosika, L. F. 1989. National Assessment and Effects of Sea level Rise on the Nigerian Coastal Zone. Report to the University of Maryland, 31pp.

Joab-Peterside, S. 2012. Corruption issues in the Federal Government's Amnesty Programme for Ex-Militants in the Niger Delta, State and Society, An Inter Disciplinary Journal of Nigerian Sociological Society, Volume 2, No.1, November.

Joab-Peterside, S.; Porter, D; and Watts, M. 2012. Rethinking Conflict in the Niger Delta: Understanding Conflict Dynamics, Justice and Security. Department of Geography \& Institute of International Studies, University of California, Berkeley, United States of America(USA).

Joab-Peterside, 2014. Oil Theft and Artisanal Refining in the Niger Delta: Dynamics and Socio-Economic Implications. Port Harcourt Journal of Social Sciences. A Publication of the Faculty of Social Sciences, 
University of Port Harcourt. Volume 5 Numbers $1 \& 2$.

Joab-Peterside, 2015. Reform of the Oil and Gas Sector in Nigeria from 1999-2012: Prospects and Challenges.Port Harcourt Journal of Social Sciences. A Publication of the Faculty of Social Sciences, University of Port Harcourt. Volume 6.

Joab-Peterside, 2018. Managing Technical Impacts of Oil and Gas Business: Local Content, Environment, Transparency and Accountability Issues. Developing Countries Studies Vol. 8.

Moffat, D. and Linde, O. 1995. Perception and Reality: Assessing Priorities for Sustainable Development in the Niger River Delta. A Journal of The Human Environment. Royal Swedish Academy of Sciences.

Niger Delta Wetlands Centre, 1995. "Review of Initial Assessment of Environmental Issues in the Niger Delta and "Niger Delta Biodiversity". Report by the Niger Delta Wetland Centre, Port Harcourt, Nigeria.

Nigerian Compass, 2012. Toward Achieving Zero Level Gas Flare. Monday April 23.

Nwankwo, J. N. 1984. Oil and environmental pollution, Paper presented at the conference on strategies for the $5^{\text {th }}$ National Development Plan 1986-1990, NISER, November(Ibadan).

Obayanju, B. 2011. The ABC of Gas Flares. In Gas Flares \& The Laws. Environmental Impact. A Newsletter of Environmental Rights Action/Friends of the Earth Nigeria, Benin City.

Obodekwe, S. Strange Black Soot Blankets Port Harcourt-Vanguard https// www.vanguard.com.2017/strangeblack-soot -blankets... accessed $21^{\text {st }}$ March, 2017.

Oduchi, G. O. 1992. Effects of oil pollution on property values, paper presented at the $22^{\text {nd }}$ Annual Conference of Nigerian Institute of Estate Surveyors and Valuers. March (Port Harcourt).

Okey, E. N.; Umana, E. J.; Markson, A. A. and Okey, P. A. 2013. Municipal Solid waste characterization and management in Uyo, Akwa Ibom State, Nigeria. Sustainable Development and Planning VI 639. WIT Transactions on Ecology and The Environment, Vol 173, @2013 WIT Press www.witpress.com, ISSN 17433541(on-line

Oil Mineral Producing Area Development Commission(OMPADEC) undated. Files and Documents relating to environmental pollution from oil spill accidents, 1994-1997.

Omiyi, B. (2001),Shell Nigeria Corporate Strategy for Ending Gas Flaring, a paper presented at a seminar on Gas Flaring and Poverty Alleviation in Oslo, Norway, June 18-19, 2001.

Popoola, T., Five ways to live healthy with black soot pollution in Port Harcourt. Accessed 23/11/2018.

Rangeley, R. 1994. International River Basin Organization in Sub-Saharan Africa. Technical Paper 250. World Bank, Washington DC.

Remani-Abah Consultants. 1997. Compensation practice in Nigeria: a review of current trends. Technical Report 13.Remani-Abah Consultants.

Sayne, A. 2010. Antidote to Violence? Lessons for Nigerian Federal Government's 10 percent community royalty from the oil experience. Niger Delta Report, No.1 9 February 2010. International Crisis Project. Washington, DC. United States of America.

Stakeholder Democracy Network(SDN), 2010. The Challenges Facing Shell in the Niger Delta. In Shell in the Niger Delta: A Framework for Change. Five case studies from civil society. Sponsored by Cordaid, Oxford, UK.

Technical Committee on the Niger Delta, 2008. Report of the Technical Committee on the Niger Delta(RTCND), Volume 1. November 2008.

Transnational Crisis Project, 2010. Antidote To Violence? Lessons for the Nigerian Federal Government's ten percent Community Royalty from the oil experience. Niger Delta Report, No. 1. 9 February. Transnational Crisis Project, Washington, D.C. United States of America.

Ugwoke-Omene, O. 2004. Niger Delta: Sustainable development challenges. THE GUARDIAN, Monday, April 5, 2004. Lagos, Nigeria.

United Nations Environmental Programme, (UNEP), 2011. Environmental Assessment of Ogoniland. United Nations Environmental Programme. Nairobi, Kenya.

United States Energy Association(undated): Global Reduction Public-Partnership.

Vanguard, 2017. "Strange black soot" blankets ParcourtVanguardhttps://ww.vanguardngr.com.2017/strange-black-soot-blankets... accessed 21 $1^{\text {st }}$ March, 2017.

Watts, M. 2015. Chronicle of a Future foretold: The Complex Legacies of Ken Saro-Wiwa. The Extractive Industries and Society. 2015 Elsevier Ltd. 